Egyptian Poultry Science Journal

http://www.epsaegypt.com

ISSN: 1110-5623 (Print) - 2090-0570 (On line)

\title{
EFFECTS OF ADDING MANNAN OLIGOSACCHARIDE AND B_GLUCANS IN DIET ON PRODUCTIVITY AND IMMUNITY LEVEL OF RABBITS
}

\author{
Marwa, Kharboush A. ; El-Raffa, A.M.; El-Dlebshany, Amira E.; Ataa A.M.A. and \\ *Fahmi, K.N.
}

Poul. Prod..Dept., Fac. of Agric.e, Alexandria Univ.Nutr.and Clinic.Nutr. Dept., Fac. of

Veter. Medic. , Cairo Univ

Corresponding auther: amiraeldlebshany@yahoo.com

Received: 31/08/2016 Accepted:05/11/2016

ABSTRACT:This study was designed to investigate the effect of adding combination of Mannan Oligosaccharide and $\beta$ Glucans (Agrimos) in diet on productivity and immunity level of does and follow this effect of adding on growing rabbits. At the first experiment: A total of $64 \mathrm{~V}$-Line Does at 5 months of age with an average body weight $(3.4 \pm 0.23) \mathrm{Kg}$ divided randomly into 2 treatment groups ( $\mathrm{n}=32$ does per group) which received two experimental diets (the basal diet for control group and $2 \mathrm{~kg}$ Agrimos /Ton basal diet for treatment group). At the second experiment: From the third parity at 4 week of ages a total number of 108 unsexed weaned V- Line rabbits which produced of each group does (control and treatment does) from the first experiment, was divided into three equal groups each group consisted of 36 rabbits ( $1^{\text {st }}$ group was fed a basal diet and served as control; $2^{\text {nd }}$ group was fed a basal diet with $1 \mathrm{~kg}$ Agrimos/ ton and $3^{\text {rd }}$ group was fed a basal diet with $2 \mathrm{~kg}$ Agrimos/ ton.). Results of the current study are summarized as follows: The does which fed diet contained $2 \mathrm{~kg}$ Agrimos /Ton basal diet for treatment group recorded higher litter size at birth (10.41) than its fed basal diet (9.44) with significant differences. Also, the corresponding values of bunny number at weaning were (7.19) higher than its (6.62) but without significant differences. Also, the treated does ( $2 \mathrm{~kg}$ Agrimos /Ton basal diet) resulted in increases of white blood cells $\left(\mathrm{WBC}^{*} 10^{3}\right)$, lymphocyte, Mid and IgG comparing with control does $\left(8.98 * 10^{3}, 52.59 \%, 10.82 \%\right.$ and $691.39 \mathrm{mg} / \mathrm{ml}$ vs $8.29 * 10^{3}, 44.55 \%$, $10.16 \%$ and $597.75 \mathrm{mg} / \mathrm{ml}$, respectively). These results indicated that improving of immunity level for treated doe rabbits by adding Agrimos in diet.Mean of body weight gain from 4 to 10 wks of age for growing rabbits which producing of treated does (1253.53 $\mathrm{g} / 2 \mathrm{wks} /$ rabbit) had higher growth than its producing of control does $(1076.60 \mathrm{~g} / 2 \mathrm{wks}$ /rabbit) with significant differences. Also, the highest body weight gain from 4 to $10 \mathrm{wks}$ of age (1292.00 g/2wks/rabbit) was obtained of fed $1 \mathrm{~kg}$ Agrimos/ ton basal diet for growing rabbits producing of treated does during the period of weaning to 10 wks of age. Means of white blood cells (WBC*10 $0^{3}$ ), lymphocyte and Mid for growing rabbits which producing of treated does $\left(9.83^{*} 10^{3}, 46.49 \%\right.$ and $11.53 \%$, respectively) were higher values than its producing of control does $\left(9.15^{*} 10^{3}, 42.87 \%\right.$ and 10.81 , respectively). In conclusion, adding Mannan Oligosaccharide and $\beta$ _Glucans (Agrimos) in rabbits diets significantly improved litter size at birth and immunological status of doe rabbits. And also, body weight gain from 4 wks to $10 \mathrm{wks}$ and immunological status of growing rabbits.

Key Words: Mannan Oligosaccharide- $\beta$ _Glucans-productivity- immunity-rabbits. 


\section{INTRODUCTION}

During the commercial husbandry of rabbits problems always occur with infections of stomach and intestine. Prebiotics have been shown to alter gastrointestinal microflora, alter the immune system, reduce pathogen invasion including pathogens such as Salmonella spp. and E. coli (Cummings and Macfarlane, 2002). Prebiotics usually refers to oligosaccharides which are not digested by the animal enzymes (Falcao et al., 2007).

Oligosaccharides such as Mannan Oligosaccharide are supposed to selectively stimulate the beneficial microbes that already live there. Oligosaccharides have two clear advantages relative to probiotics: a technological one, because there are no critical problems with the thermal processing of the feed and the acid conditions of the stomach, and a safety one, because they do not introduce foreign microbial species into the gut (Falcao et al., 2007). Mannan oligosaccharides are indigestible complex polysaccharide molecules derived from yeast cell walls. Mannose is a monosaccharide that forms the building block of MOS. The small intestine does not contain the digestive enzymes required to break down mannan oligosaccharide bonds, therefore they arrive at the large intestine intact after ingestion and passage through the small intestine (Strickling et al. 2000). In rabbit production, mannan oligosaccharides (MOS) are considered promising prebiotics (Bovera et al., 2010). Attia et al. (2015a) reported that all the supplements and prebiotics (MOS $35 \mathrm{mg} / \mathrm{kg} \quad \mathrm{BW}$ ) had similar ability to decrease the number of services to achieve pregnancy and to increase fertility than the control group; groups receiving supplements or prebiotics (MOS) had greater litter size, body weight of kits at birth and number of kits born alive than the control; groups receiving supplements or prebiotics (MOS) highest growth of kits, milk yield and milk conversion ratio during days $1-28$ of age than the control group. $\beta$-glucans are carbohydrate polymers consisting entirely of glucose. $\beta$-glucans have been reported to modulate cytokine profiles and phagocyte activity and natural killer cell function (Anders et al., 2008). The $\beta$ glucan component in the Saccharomyces cerevisiae cell wall, with the function of maintaining the rigidity and shape of the cell, is often named simply glucan or yeast glucan. That polysaccharide consists mainly of a linear central backbone of Dglucose linked in the $\beta-(1 \rightarrow 3)$ position with glucose side branches $(\beta-(1 \rightarrow 6)$-linkage) of various sizes, which occurs at different intervals along the central backbone (Gardiner, 2000). The innermost layer of the yeast cell wall is built of $\beta$-glucans, proteins, mannan and small amounts of chitin (Vetvicka, 2001). Shendare et al ,2008 reported that the inclusion of growth promoter Mannan oligosaccharide \& $\beta$ glucans shows significantly higher body weight gain, improvement in feed efficiency and less mortality as compared to the control diet.This study was designed to investigate the effect of adding combination of Mannan Oligosaccharide and $\beta$ _Glucans in diet on productivity and immunity level of does and follow this effect of adding on growing rabbits.

\section{MATERIALS AND METHODS}

The present study was carried out at the Poultry Research Center, Poultry Production department, Faculty of Agriculture, Alexandria University, during the period from November 2013 to June 2014.

\section{Experimental animals:}

The rabbits (Oryctolagus cuniculus) used in the current study were known as the $\mathrm{V}$ 
line rabbits. Line $\mathrm{V}$ is a developed maternal line originated in 1981 at the Department of Animal Science of the Universidad Politecnica de Valencia, Spain (Baselga, 2002). Litter size at weaning was considered as the criterion for selection in this line. $\mathrm{A}$ set of $\mathrm{V}$ line rabbits was imported to poultry research centre, Alexandria University at the end of year 1998 (El-Raffa, 2000) multiplied for five years and after that the selection was continued under the same criterion.

\section{Housing and Management:}

Breeding does and bucks were housed individually in commercial type wire cage batteries with standard dimensions of (75x $50 \times 40 \mathrm{~cm}$ ) for length, width and height, respectively allocated in two rows along the house. Cage of each doe was provided with a metal box with dimensions of (40x $35 \times 30 \mathrm{~cm}$ ) for kindling. The batteries used were suspended $110 \mathrm{~cm}$ above floor level. Cages of all does were cleaned at the same above the first experiment. Mating was carried out in the morning, each doe was transferred to buck's cage to mated and returned to her cage after mating bred pregnancy was diagnosed by abdominal palpation at the 14 days post mating to determine pregnancy.

Does were failed to conceive were immediately returned after palpation to the buck for another service till conception was occurred. On the $26^{\text {th }}$ day of pregnancy, the nest boxes were supplied with thick layer of rice straw was placed in the bottom of the nest box to help the doe in preparing a worm comfortable nest for her bunnies. Nesting boxes were attached to the cages of pregnant does. At the $33^{\text {rd }}$ day of pregnancy, the birth was released by an injection of oxytocin in case the doe had not littered until then. Litters born were examined and recorded for total litter size born, litter size born alive and litter weight at birth. Does were reamed 10-11 days after kindling (semi-intensive system). At four weeks of age, bunnies were weaned, sexed, individually weighted, and ear-numbered by tattoo machine and transferred to the progeny cages in groups of 4 rabbits per cage for the fattening period.

Growing rabbits were housed in galvanized wire cage battery with standard dimensions of $(50 \times 45 \times 40 \mathrm{~cm})$ for length, width and height, respectively. The batteries used were suspended $110 \mathrm{~cm}$ above floor level. The cage of each battery has girded wire floor separated the rabbits completely from its excreta. All rabbits were kept under the same hygienic and environmental conditions during the experimental period.

\section{Experimental designs:}

\subsection{The First Experiment:}

A total of $64 \mathrm{~V}$-Line Does at 5 months of age with an average body weight (3.4 \pm $0.23) \mathrm{Kg}$ of V-Line females and with 16 bucks ( 1 buck :4 does) at 6 months of age an average body weight $(3.22 \pm 0.20) \mathrm{Kg}$ allocated for two treatments (figure 1). Rabbits were randomly divided into 2 treatment groups ( $\mathrm{n}=32$ doe per group) which received two experimental diets (the basal pellet diet contained $17.87 \%$ crude protein, $14.62 \%$ crude fiber, $2.70 \%$ fat and $2592 \mathrm{kcal} / \mathrm{kg}$ diet and provided with all required vitamins and minerals as recommended by N.R.C, 1994). Data were collected on each doe of the two groups for three successive parturitions during the experiment period of the study.

1. Control group which received the basal diet.

2. Treatment group which received $2 \mathrm{~kg}$ Agrimos (Mannan Oligosaccharide and $\beta \_$Glucans) /Ton of the basal diet.

\subsection{The Second Experiment (Growing rabbit):}

From the third parity at 4 week of ages a total number of 108 unsexed weaned VLine rabbits which produced of each group 
does (control and treatment does) from the first experiment, was divided into three equal groups (36 rabbits in each) used in the present experiment. Each group was divided into three equal replicates.

The three groups which produced of each of control or treatment does were fed the same basal diet and submitted to the following treatments (figure 1).

$1^{\text {st }}$ group was fed a basal diet and served as control.

$2^{\text {nd }}$ group was fed a basal diet with $1 \mathrm{~kg}$ Agrimos/ ton.

$3^{\text {rd }}$ group was fed a basal diet with $2 \mathrm{~kg}$ Agrimos/ ton.

\section{Data collected}

\subsection{Reproductive performance:}

Data were collected on does traits were conception rate (CR), number born alive (NBA) and number born dead (NBD) and litter size at birth (LSB) and bunny number at weaning $(\mathrm{NW})$, for litters produced by 32 does from each treatment which inseminated by fertile bucks for 3 consecutive parities.

\subsection{Live Body Weight Gain (LBWG):}

Individual body weight was biweekly taken from the beginning of 4 week of age until the end of the experiment at 10 weeks of age. Weighing was done in the morning before receiving feed and water. Live body weight gain was calculated by subtracting the initial live body from final ones of each growth through studied period.

\subsection{Immunity level:}

At the first experimental, Blood samples were carried out every one day after parturition from five doe (randomly chosen) in the treated groups and continued throughout the experimental period. However, at the end of second experimental period (10 weeks of age), total number of 30 animals were fasted overnight then sacrificed (5 rabbit/group). Blood samples were withdrawn from the central ear artery in clean and dried Wiesserman tubes, heparin was used as anticoagulation but in part of samples, it was with held to obtain serum. Serum was obtained by centrifugation the blood at $3000 \mathrm{rpm}$ for 20 minutes, and was stored at- $20 \mathrm{C}$ for later analysis.

\subsubsection{Blood hematological parameters:} White blood cells (WBC $\times \mathbf{1 0}^{3}$ ) counts: White blood cells counts were counted in fresh blood sample as the method described by Helper (1966), and Hawkeye \& Dennett (1989), were counted on an AOB right line haemocytometer using a light microscope at $400 \mathrm{X}$ magnification after diluting blood samples 200 times with a physiological saline $(0.9 \% \quad \mathrm{NaCl}$ solution) before counting.

\section{White Blood Cell Differential count:}

Determines the percentage of Lymphocyte; Heterophils; mid-range percent (Mid\%) and Heterophils / Lymphocyte ratio (H/L).

4.3.2. Blood biochemical characteristics: Serum immunoglobulin types IgG (mg/mL):

Serum immunoglobulin types $\operatorname{IgG}$ were determined using ELISA technique 


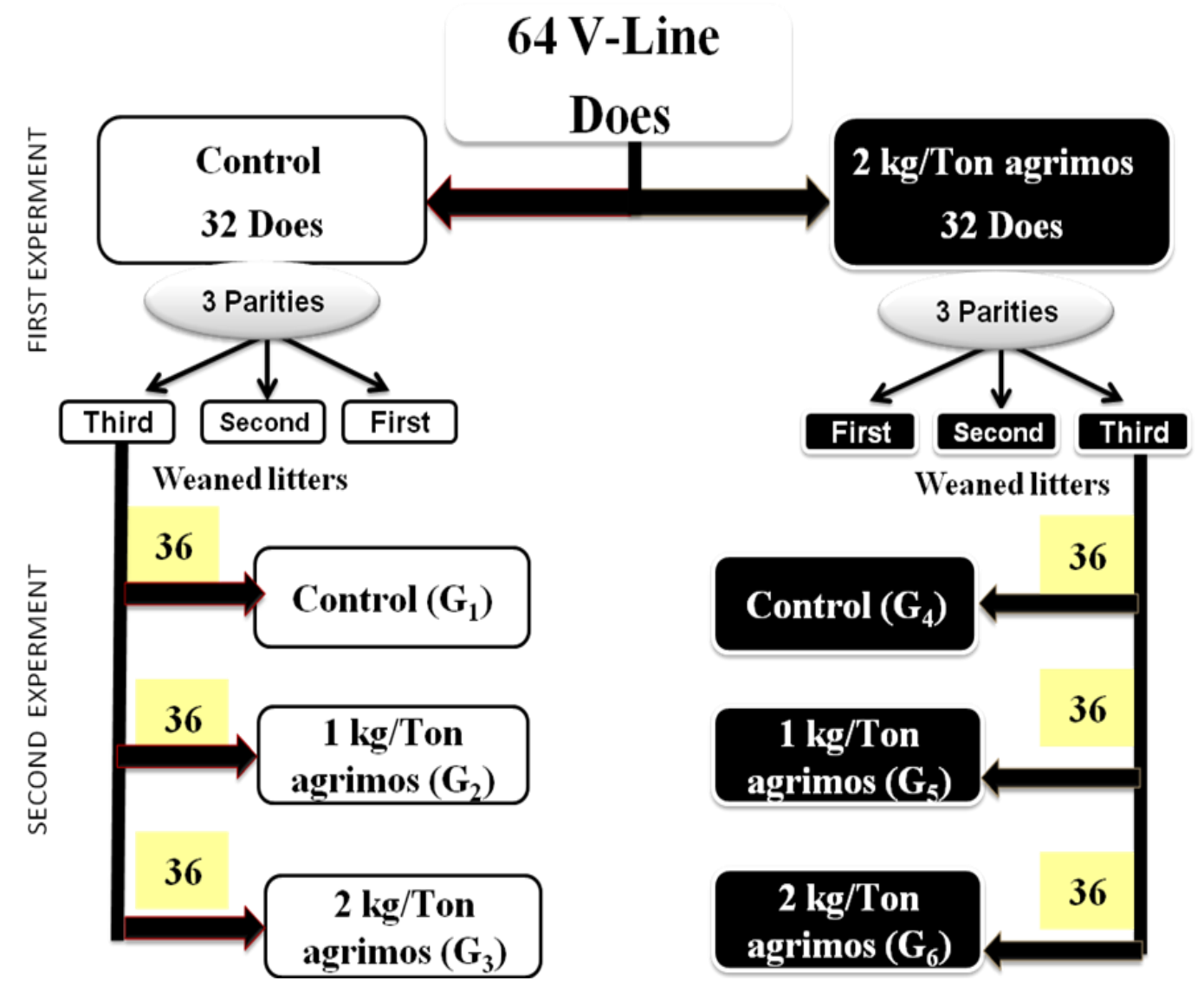

Figure(1): A representative drawing for the experimental design .

\section{Statistical Procedure:}

The statistical analyses of the data were carried out by using the international software program (SAS, 2003). Data were analyzed by adapting the following fixed linear model: The application of the least significant ranges among different treatment means was done according to Duncan (1955).

The following statistical model was used in the first experiment:

$Y_{i j k}=\mu+T_{i}+P_{j}+(T P)_{i j}+e_{i j k}$

$\mathrm{Y}_{\mathrm{ijk}}=$ The observation of the parameter measured,

$\mu=$ The overall mean,

$\mathrm{T}_{\mathrm{i}}=$ The effect of dietary treatment for doe rabbits, $\mathrm{i}=(1,2)$,

$\mathrm{P}_{\mathrm{j}}=$ The effect of parity, $(\mathrm{j}=1,2$ and 3$)$,
$(\mathrm{TP})_{\mathrm{ij}}=$ Interaction between parity and treatment,

$\mathrm{e}_{\mathrm{ijk}}=$ The experimental random error.

The following statistical model was used in the second experiment:

$\mathrm{Y}_{\mathrm{ijk}}=\mu+\mathrm{D}_{\mathrm{i}}+\mathrm{T}_{\mathrm{j}}+(\mathrm{DT})_{\mathrm{ij}}+\mathrm{e}_{\mathrm{ijk}}$

Where:

$\mathrm{Y}_{\mathrm{ijk}}=$ The observation of the parameter measured,

$\mu=$ The overall mean,

$\mathrm{D}_{\mathrm{i}}=$ The effect of treatment Does at first experiment, $\mathrm{i}=(1,2)$,

$\mathrm{T}_{\mathrm{j}}=$ The effect of dietary treatment for growing rabbits, $\mathrm{j}=(1,2,3)$,

$(\mathrm{DT})_{\mathrm{ij}}=$ Interaction between Doe and treatment,

$\mathrm{e}_{\mathrm{ijk}}=$ The experimental random error. 


\section{RESULTS AND DISCUSSION}

\subsection{The first experiment on doe rabbits:}

\subsubsection{Effect of Mannan Oligosaccharide} and $\beta$ Glucans supplementation in diet for different parities on reproductive traits:

Results in Table (1) show that the effect of Mannan Oligosaccharide and $\beta$ Glucans level (2 $\mathrm{kg}$ Agrimos/ ton feed) supplementation in diet of doe rabbits Vline on conception rate (\%) (CR), number born alive (NBA), number born dead (NBD), litter size at birth (LSB) and bunny number at weaning (NW). Analysis of Variance data indicated that the NBD and LSB was significantly $(\mathrm{P} \leq 0.05)$ higher in Agrimos treatment than control does. The percentages of that increase of Agrimos treatment compared with control were $70.27 \%, 10.28 \%$ respectively, but CR; NBA and NW were not significant affected. Moreover, the results of Table (1) revealed that overall mean of LSB at the parity three was increased significantly compared with parity two by $9.39 \%$ but were not significant with parity four, but CR; NBD and NW were not significant affected by parity number.

Concerning of the interaction effect between the Agrimos levels and the parity number were not statistically significantly effect on C.R; NBA; NBD; LSB and NW.

Results herein are in a good agreement with that obtained by Wu et al., (2011) who noted dietary supplementation of $0.064 \%$ $\beta-1,3-1,6$-glucan or $0.128 \% \quad \beta-1,3-1,6-$ glucan had no adverse effects on the reproductive performance and body weight of does.

In line with the present findings, Attia et $a l .$, (2015a) reported that groups receiving prebiotics (MOS) of V-line doe rabbits had greater litter size than the control. The prebiotics (MOS $35 \mathrm{mg} / \mathrm{kg} \quad \mathrm{BW}$ ) had similar ability to decrease the number of services to achieve pregnancy and to increase fertility than the control group.

\subsubsection{Effect of Mannan Oligosaccharide and $\beta$ Glucans supplementation in diet for different parities on immunity parameters:}

The effects of Mannan Oligosaccharide and B_Glucans level (2 kg Agrimos/ ton feed) supplementation in diet on does rabbits VLine blood white blood cells count (WBCs); Lymphocyte; Heterophils; Lymphocyte/ Heterophils ratio (H/L); midrange percentage (Mid \%) and immunoglobulin $\mathrm{G}(\mathrm{IgG})$ in blood at one day after parturition presented in Table (2). It is clear from the data that the Lymphocyte was significantly $(\mathrm{P} \leq 0.05)$ higher in Agrimos treatment than control group at one day after parturition. The percentage of that increase of Agrimos treatment compared with control was 18.05 $\%$.

Additionally, the doe rabbit's Lymphocyte/ Heterophils ratio $(\mathrm{H} / \mathrm{L})$ was significantly $(\mathrm{P} \leq 0.05)$ higher in control treatment than Agrimos does at one day after parturition. The percentage of that increase of control treatment compared with Agrimos was $19.64 \%$.which indicate that $2 \mathrm{~kg}$ Agrimos/ ton feed supplementation in diet improved immunity level of doe rabbits .Whereas, WBC; Heterophils and Mid \% were not significant, additionally blood $\mathrm{IgG}$ tend to be higher insignificantly in Agrimos treatment than control does at one day after parturition .The doe rabbit's IgG was significantly $(\mathrm{P} \leq 0.05)$ increased with the increasing of the parity number at one day after parturition. The percentages of that increase compared with the parity two were $(29.07 \%$ and $35.34 \%)$ with the parity three and four, respectively. But, WBCs; Lymphocyte; Heterophils; H/L and Mid \% were not significant. Also, it can be observed that the interactions effect between the Agrimos level and the parity number were statistically significant $(\mathrm{P} \leq 0.05)$ on Lymphocyte; $\mathrm{H} / \mathrm{L}$ and $\mathrm{IgG}$, whereas there was a non-significant different in on WBC; Heterocyte and Mid 
$\%$ between the Agrimos level and the parity numbers.

It is clear from the data that Lymphocyte value was significantly $(\mathrm{P} \leq 0.05)$ higher in Agrimos level and parity numbers (53.79, 52.04 and 51.94) than the $0 \mathrm{~kg}$ agrimos and the different parity numbers $(44.22,43.82$ and 45.60), respectively.

Also, blood IgG was significantly $(\mathrm{P} \leq 0.05)$ higher in all group compared with control does in parity two. The percentages of that increase compared with the control were (50.8, 62.6, 44.7, 65.0 and $68.5 \%$ ), respectively. But, $\mathrm{H} / \mathrm{L}$ ratio was significantly $(\mathrm{P} \leq 0.05)$ lower in Agrimos level and parity numbers $(0.55,0.58$ and 0.56) than the $0 \mathrm{~kg}$ agrimos and the different parity numbers $(0.65,0.71$ and 0.66), respectively. May be, this data indicates that the addition of Agrimos with $2 \mathrm{~kg} / \mathrm{ton}$ may be the reason for the increase blood IgG level in does rabbits V-Line in parity number two.These results are generally similar to those reported by Wu et al., (2011) and Attia et al., (2015a). Who noted dietary supplementation with $0.064 \%$ $\beta-1,3-1,6$-glucan significantly inhibited delayed-type immune reaction of Th1 and significantly reduced serum $\mathrm{IgG}$ concentration of does at the late gestation stage but increased serum $\operatorname{IgM}$ and $\operatorname{IgG}$ concentrations at the late lactation stage.

\subsection{The second experiment on growing rabbits:}

\subsubsection{Effect of Mannan Oligosaccharide and $\beta$ _Glucans supplementation in diet on live body weight gain (LBWG) of growing rabbits:}

Summarized in Table (3) are average live body weight gain of V-line growing rabbits as affected by dietary inclusion levels of Agrimos throughout the entire growth periods 4-6, 6-8, 8-10 and 4-10 weeks of age as experimental period. Analysis of variance data indicated that body weight gain of the two treatments was gradually increased with the increasing of the rabbit's age. Body weight gain of growing rabbit from treated does $(2 \mathrm{~kg} /$ ton Agrimos) was significantly $(\mathrm{P} \leq 0.05)$ higher by $21.39 \%$ and $16.43 \%$ than that of untreated does at 8-10 and 4-10 weeks.

In respect of the Agrimos levels effect regardless the treated does, the results revealed that there was increased with the increasing of the Agrimos levels, but nonsignificant on live body weight gain entire growth periods 4-6, 6-8, 8-10 and 4-10 weeks of age as experimental period.

Also, it can be observed that the interactions effect between the treated does and the Agrimos levels were statistically significant $(\mathrm{P} \leq 0.05)$. The total values of the interaction from ( 8 to 10 and 4 to 10 weeks of age) were significantly $(\mathrm{P} \leq 0.05)$ higher with the higher AGRIMOS levels compared with the control and the lower levels.Interesting enough at the experimental period that body weight gain of the treated rabbits was significantly $(\mathrm{P} \leq 0.05)$ better after 4 weeks when the Agrimos was added to the diet compared with the control group. In that, average gain of G4 and G5 were higher by $36.08 \%$ and $33.16 \%$, respectively over that $\mathrm{G} 1$ at $8-10$ and 4-10 weeks.

In connection, Kocher et al ., 2004 suggested that the MOS increased body weight gain; the use of Agrimos $^{\circledR}$ stimulated the overall daily gain compared to the OTA group Awaad et al., (2011); Bovera et al., (2010) mannanoligosaccharides showed a positive effect on growth performance. The best results were obtained with a concentration of 1.0 $\mathrm{g} / \mathrm{kg}$ diet of MOS. Shendare et al., (2008) reported that the inclusion of growth promoter Mannan oligosaccharide \& $\beta$ glucans shows significantly higher body weight gain as compared to the control diet.Mannan oligosaccharides administered continuously or intermittently increased $(\mathrm{P}<0.05)$ body weight gain in respect of the control group (Attia et al., 2015b). Rabbits fed diets 100 and $150 \mathrm{ppm}$ of Fibosel $\beta$ glucans), respectively showed a $13.5 \%$ 
higher body weight gain, as average, than rabbits fed the control diet (Garcia-Ruiz et al., 2008).

4. 2.2. Effect of Mannan Oligosaccharide and $\beta$ _Glucans supplementation in diet on immunity parameters of growing rabbits:

Changes in White blood cells count (WBCs); Lymphocyte percent (Lymph\%); Heterophils percent (Hetero\%); Heterophils/ Lymphocyte ratio (H/L); midrange percent (Mid\%) in blood and Immunoglobulin $\mathrm{G}$ (IgG) concentration $(\mathrm{mg} / \mathrm{ml})$ in blood serum added Mannan Oligosaccharide and $\beta$ Glucans (Agrimos) in V-line growing rabbits diet are presented in Table (4). Analysis of variance data indicated that a slightly increase but not significant in WBC count and Mid \% of Agrimos treated does ( $2 \mathrm{~kg}$ Agrimos/ton), also $\mathrm{IgG}$ concentration was not significantly different between growing rabbits of control and treated does. But the Lymphocyte \% was significantly $(\mathrm{P} \leq 0.05)$ higher by $8.4 \%$ in treated does than control group. While, the percentage of that increase of control group compared with treated does by $2 \mathrm{~kg}$ Agrimos in Heterophils cells and $\mathrm{H} / \mathrm{L}$ ratio was $(4.6 \%$ and $13.3 \%$ ), respectively.

In respect of the Agrimos levels affect regardless the treated does the growing rabbit's serum Immunoglobulin $\mathrm{G}$ ( $\mathrm{IgG}$ ) concentration was significantly $(\mathrm{P} \leq 0.05)$ increased with increasing the Agrimos levels at 10 weeks of age. The percentages of that increase compared with the controls were $(1.4 \%$ and $13.2 \%)$ with (1 and $2 \mathrm{~kg}$ Agrimos/ Ton diet) at the end of experimental period, respectively. It can be observed also that White blood cells count (WBCs); Lymphocyte percent (Lymph \%); Heterophils percent (Hetero \%) and midrange percent (Mid \%) in blood of Agrimos levels were increased with increasing the Agrimos levels, but not significantly affected at 10 weeks of age.

Also the interaction effect between treated does and the Agrimos levels was not statistically significant in WBCs count at the end of experimental period. While, the interaction effect was statistically significant $(\mathrm{P} \leq 0.05)$ on Lymph \%, Hetero $\%, \mathrm{H} / \mathrm{L}, \mathrm{Mid}$ and $\mathrm{IgG}$ concentration. The higher percentage was recorded with the control group (G1) and growing rabbits treated with $1 \mathrm{~kg}$ Agrimos (G2) than other groups at Hetero $\%$ and $\mathrm{H} / \mathrm{L}$, while, the higher percentage at Lymph \%, Mid \% and IgG were recorded with G5 and G6 of growing rabbits than other groups. These results are agreement with Savage et al., 1996, Santin et al., 2001, Shane, 2001 and El-Sheikh et al., 2009. Who showed that MOS had the ability to stimulate elevated antibody levels, especially $\operatorname{IgG}$ and $\operatorname{IgA}$ levels. The results may be due to that the immune system has evolved primarily to protect the host against invading pathogens including viruses, bacteria, yeasts, protozoa and multi-cellular parasites.

\section{CONCLUSION}

The results concluded that adding Mannan Oligosaccharide and $\beta$ _Glucans (2 kg Agrimos/ton basal diet) in doe rabbits diet of V-line was efficient in improving litter size at birth, bunny number at weaning, litter bunnies weight till weaning and immunity level. Moreover, adding Mannan Oligosaccharide and $\beta_{-}$Glucans (1 kg Agrimos/ ton basal diet) in growing rabbits diet had beneficial effects on body weight gain and immunity level for growing rabbits from 4 wks to 10 wks of ages. 
Table ( 1 ): Least Square Means \pm SE of Conception rate (CR \%), number born alive (NBA), number born dead (NBD)and litter size at birth (LSB)) and bunny number at weaning (NW) added Mannan Oligosaccharide and $\beta$ _Glucans (Agrimos) in V-line doe rabbits diet.

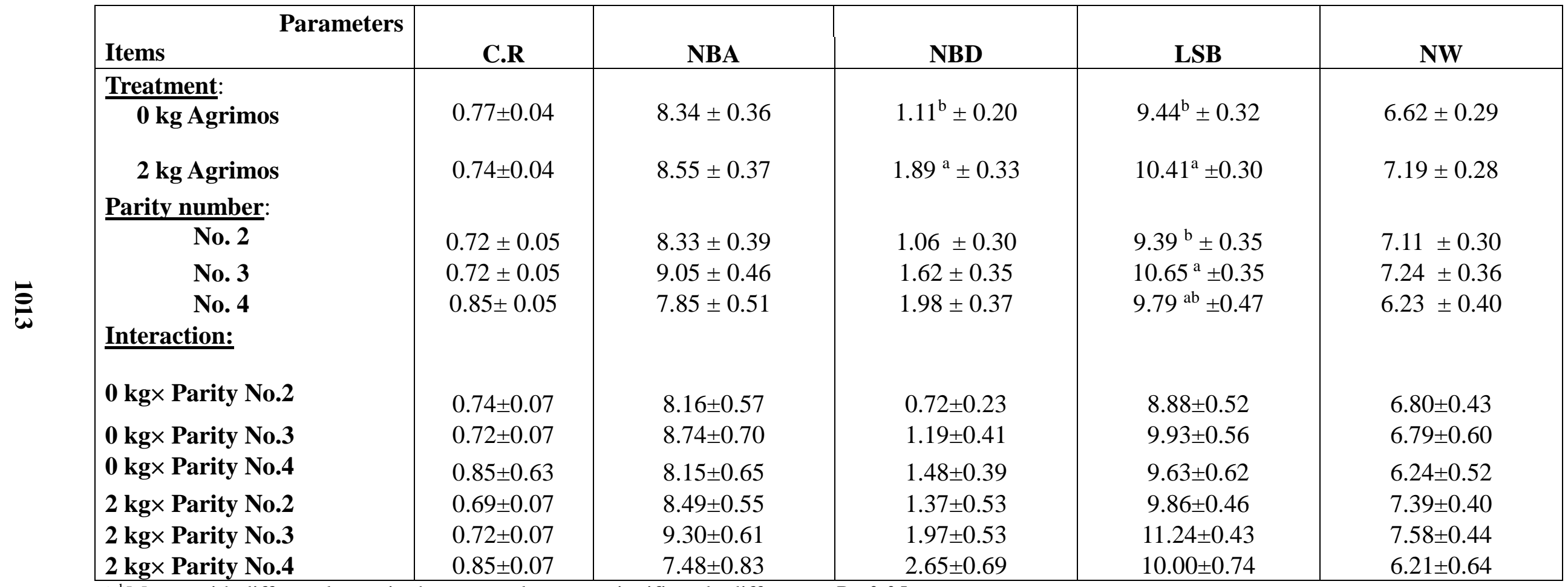

${ }^{\mathrm{a}, \mathrm{b}}$ Means with different letters in the same column are significantly different at $\mathrm{P} \leq 0.05$ 
Table ( 2): Least Square Means \pm SE of WBCs; Lymphocyte; Heterocyte; H/L; Mid and IgG for different parities with added Mannan Oligosaccharide and $\beta$ _Glucans (Agrimos) in V-line doe rabbits diet.

\begin{tabular}{|c|c|c|c|c|c|c|}
\hline Parameters & & & nunity para & & & \\
\hline Items & $\mathrm{WBC}^{*} \mathbf{1 0}^{3}$ & Lymph \% & Heter \% & $H / L$ & Mid\% & IgG $\quad(\mathrm{mg} / \mathrm{ml})$ \\
\hline$\frac{\text { Treatment: }}{0 \text { kg Agrimos }}$ & $8.29 \pm 0.42$ & $44.55^{b} \pm 0.71$ & $29.85 \pm 0.58$ & $0.67^{\mathrm{a}} \pm 0.02$ & $10.16 \pm 0.37$ & $597.75 \pm 44.10$ \\
\hline 2 kg Agrimos & $8.98 \pm 0.37$ & $52.59^{\mathrm{a}} \pm 0.99$ & $29.43 \pm 0.44$ & $0.56^{\mathrm{b}} \pm 0.02$ & $10.82 \pm 0.47$ & $691.39 \pm 36.37$ \\
\hline$\frac{\text { Parity number: }}{\text { No. } 2}$ & $8.38 \pm 0.67$ & $49.01 \pm 2.03$ & $29.15 \pm 0.63$ & $0.60 \pm 0.02$ & $10.12 \pm 0.63$ & $530.64^{\mathrm{b}} \pm 53.23$ \\
\hline No. 3 & $8.50 \pm 0.34$ & $47.93 \pm 1.71$ & $30.32 \pm 0.52$ & $0.64 \pm 0.03$ & $10.79 \pm 0.40$ & $684.90^{\mathrm{a}} \pm 40.35$ \\
\hline No. 4 & $9.03 \pm 0.43$ & $48.77 \pm 1.32$ & $29.44 \pm 0.70$ & $0.61 \pm 0.03$ & $10.57 \pm 0.53$ & $718.16^{\mathrm{a}} \pm 36.33$ \\
\hline$\frac{\text { Interaction: }}{0 \mathrm{~kg} \times \text { Parity No.2 }}$ & $8.28 \pm 1.07$ & $44.22^{b} \pm 1.43$ & $28.91 \pm 0.92$ & $0.65^{\mathrm{ab}} \pm 0.02$ & $10.08 \pm 0.83$ & $433.80^{\mathrm{b}} \pm 26.15$ \\
\hline 0 kg $\times$ Parity No.3 & $7.74 \pm 0.24$ & $43.82^{b} \pm 1.13$ & $30.81 \pm 0.78$ & $0.71^{\mathrm{a}} \pm 0.03$ & $10.14 \pm 0.54$ & $654.10^{\mathrm{a}} \pm 55.71$ \\
\hline 0 kg $\times$ Parity No.4 & $8.86 \pm 0.71$ & $45.60^{\mathrm{b}} \pm 1.24$ & $29.81 \pm 1.27$ & $0.66^{\mathrm{ab}} \pm 0.44$ & $10.26 \pm 0.65$ & $705.35^{\mathrm{a}} \pm 61.08$ \\
\hline $2 \mathrm{~kg} \times$ Parity No.2 & $8.48 \pm 0.92$ & $53.79^{\mathrm{a}} \pm 2.25$ & $29.39 \pm 0.95$ & $0.55^{\mathrm{c}} \pm 0.31$ & $10.15 \pm 1.05$ & $627.48^{\mathrm{a}} \pm 79.30$ \\
\hline 2 kg $\times$ Parity No.3 & $9.26 \pm 0.42$ & $52.04^{\mathrm{a}} \pm 1.86$ & $29.82 \pm 0.71$ & $0.58^{\mathrm{bc}} \pm 0.02$ & $11.44 \pm 0.47$ & $715.70^{\mathrm{a}} \pm 62.15$ \\
\hline 2 kg $\times$ Parity No.4 & $9.20 \pm 0.56$ & $51.94^{\mathrm{a}} \pm 1.11$ & $29.07 \pm 0.71$ & $0.56^{\mathrm{c}} \pm 0.02$ & $10.88 \pm 0.90$ & $731.00^{\mathrm{a}} \pm 48.16$ \\
\hline
\end{tabular}

a, b, c, Means with different letters in the same column are significantly different at $\mathrm{P} \leq 0.05$ 
Table (3): Least Square Means \pm SE of body weight gain (g/ rabbit) added different level of Mannan Oligosaccharide and $\beta$ Glucans (Agrimos) in V-line growing rabbits diet.

\begin{tabular}{|c|c|c|c|c|c|}
\hline \multirow{2}{*}{\multicolumn{2}{|c|}{ Parameters }} & \multicolumn{4}{|c|}{ Body weight gain (g / rabbit) } \\
\hline & & 4-6 wks & 6-8 wks & 8 -10wks & 4-10 wks \\
\hline $\begin{array}{ll}\text { Does: } & \\
& \\
& 2 \\
\text { Treatment: } & \\
& 0 \\
& 1 \\
& 2 \\
\end{array}$ & $\begin{array}{l}\text { atrol } \\
\text { grimos } \\
\text { grimos } \\
\text { grimos } \\
\text { grimos } \\
\end{array}$ & $\begin{array}{l}111.08 \pm 16.78 \\
134.23 \pm 20.14 \\
112.94 \pm 22.14 \\
105.16 \pm 22.09 \\
147.48 \pm 22.47 \\
\end{array}$ & $\begin{array}{l}342.76 \pm 24.52 \\
363.32 \pm 11.64 \\
329.62 \pm 16.10 \\
329.85 \pm 30.39 \\
400.33 \pm 23.55 \\
\end{array}$ & $\begin{array}{c}622.76^{\mathrm{b}} \pm 29.25 \\
755.99^{\mathrm{a}} \pm 27.01 \\
662.01 \pm 53.99 \\
694.63 \pm 43.75 \\
680.94 \pm 18.95 \\
\end{array}$ & $\begin{array}{c}1076.60^{\mathrm{b}} \pm 52.68 \\
1253.53^{\mathrm{a}} \pm 38.54 \\
1104.57 \pm 71.95 \\
1129.64 \pm 80.28 \\
1228.75 \pm 25.47 \\
\end{array}$ \\
\hline $\begin{array}{c}\frac{\text { Interaction: }}{\text { Control }} \\
2 \text { kg Agrimos }\end{array}$ & $\begin{array}{l}0 \text { kg Agrimos (G1) } \\
1 \text { kg Agrimos (G2) } \\
2 \text { kg Agrimos (G3) } \\
0 \text { kg Agrimos (G4) } \\
1 \text { kg Agrimos (G5) } \\
2 \text { kg Agrimos (G6) }\end{array}$ & $\begin{array}{c}96.90 \pm 28.37 \\
74.85 \pm 16.57 \\
161.50 \pm 29.41 \\
133.00 \pm 36.87 \\
143.04 \pm 40.12 \\
124.11 \pm 37.34\end{array}$ & $\begin{array}{c}318.78 \pm 22.51 \\
302.70 \pm 53.70 \\
406.80 \pm 36.76 \\
343.17 \pm 24.51 \\
363.79 \pm 6.59 \\
389.56 \pm 24.12 \\
\end{array}$ & $\begin{array}{c}576.98^{\mathrm{b}} \pm 64.15 \\
622.20^{\mathrm{ab}} \pm 54.01 \\
669.10^{\mathrm{ab}} \pm 29.87 \\
768.29^{\mathrm{a}} \pm 62.06 \\
785.17^{\mathrm{a}} \pm 41.29 \\
700.67^{\mathrm{ab}} \pm 8.09 \\
\end{array}$ & $\begin{array}{c}992.66^{\mathrm{b}} \pm 93.37 \\
999.75^{\mathrm{b}} \pm 100.95 \\
1237.40^{\mathrm{ab}} \pm 23.10 \\
1244.46^{\mathrm{ab}} \pm 69.21 \\
1292.00^{\mathrm{a}} \pm 76.60 \\
1214.33^{\mathrm{ab}} \pm 64.09 \\
\end{array}$ \\
\hline
\end{tabular}

${ }^{\mathrm{a}, \mathrm{b}}$ Means with different letters in the same column are significantly different at $\mathrm{P} \leq 0.05$.

$\mathrm{G} 1,2,3,4,5$ and 6 means Group1, 2, 3, 4, 5 and 6. 
Table (4): Least Square Means \pm SE of White blood cells count (WBCs); Lymphocyte; Heterophils; Lymphocyte/ Heterophils ratio (H/L); mid-range percent. (Mid and Immunoglobulin G (IgG) added Mannan Oligosaccharide and $\beta$ _Glucans (Agrimos) V-line growing rabbits

\begin{tabular}{|c|c|c|c|c|c|c|c|}
\hline \multirow{2}{*}{\multicolumn{2}{|c|}{$\begin{array}{l}\text { Parameters } \\
\text { Items }\end{array}$}} & \multicolumn{6}{|c|}{ Immunity } \\
\hline & & $\mathrm{WBC}^{*} 10^{3}$ & Lymph \% & Heter \% & $\mathrm{H} / \mathrm{L}$ & Mid\% & IgG $(\mathrm{mg} / \mathrm{ml})$ \\
\hline \begin{tabular}{|l} 
Does: \\
Control \\
2 kg Agrimos
\end{tabular} & & $\begin{array}{l}9.15 \pm 0.36 \\
9.83 \pm 0.43\end{array}$ & $\begin{array}{l}42.87^{\mathrm{b}} \pm 0.75 \\
46.49^{\mathrm{a}} \pm 0.90\end{array}$ & $\begin{array}{l}28.71^{\mathrm{a}} \pm 0.30 \\
27.45^{\mathrm{b}} \pm 0.36\end{array}$ & $\begin{array}{l}0.68^{\mathrm{a}} \pm 0.02 \\
0.60^{\mathrm{b}} \pm 0.02\end{array}$ & $\begin{array}{l}10.81 \pm 0.21 \\
11.53 \pm 0.34\end{array}$ & $\begin{array}{l}663.36 \pm 18.31 \\
653.36 \pm 24.79\end{array}$ \\
\hline \begin{tabular}{|l} 
Treatment: \\
0 kg Agrimos \\
1 kg Agrimos \\
2 kg Agrimos \\
Interaction \\
\end{tabular} & & $\begin{array}{l}9.22 \pm 0.47 \\
9.09 \pm 0.50 \\
10.16 \pm 0.48\end{array}$ & $\begin{array}{c}43.10 \pm 0.62 \\
45.51 \pm 1.25 \\
45.44 \pm 1.22\end{array}$ & $\begin{array}{c}27.81 \pm 0.48 \\
28.52 \pm 0.38 \\
27.92 \pm 0.41\end{array}$ & $\begin{array}{c}0.65 \pm 0.01 \\
0.64 \pm 0.02 \\
0.63 \pm 0.03\end{array}$ & $\mid \begin{array}{l}10.66 \pm 0.3 \\
11.68 \pm 0.38 \\
11.19 \pm 0.27\end{array}$ & $\begin{array}{l}627.70^{\mathrm{b}} \pm 23.83 \\
636.63^{\mathrm{b}} \pm 25.26 \\
710.75^{\mathrm{a}} \pm 21.19\end{array}$ \\
\hline $\begin{array}{l}\text { Control } \\
2 \text { kg Agrimos }\end{array}$ & $\begin{array}{l}0 \text { kg Agrimos (G1) } \\
1 \text { kg Agrimos (G2) } \\
2 \text { kg Agrimos (G3) } \\
0 \text { kg Agrimos (G4) } \\
1 \text { kg Agrimos (G5) } \\
2 \text { kg Agrimos (G6) }\end{array}$ & $\begin{array}{l}8.96 \pm 0.59 \\
8.34 \pm 0.65 \\
10.14 \pm 0.55 \\
9.47 \pm 0.76 \\
9.84 \pm 0.72 \\
10.18 \pm 0.82\end{array}$ & $\begin{array}{l}42.83^{\mathrm{b}} \pm 0.78 \\
43.16^{\mathrm{b}} \pm 1.24 \\
42.63^{\mathrm{b}} \pm 1.81 \\
43.36^{\mathrm{b}} \pm 1.00 \\
47.86^{\mathrm{a}} \pm 1.97 \\
48.25^{\mathrm{a}} \pm 1.11\end{array}$ & $\begin{array}{l}29.08^{\mathrm{a}} \pm 0.47 \\
28.94^{\mathrm{a}} \pm 0.54 \\
28.10^{\mathrm{ab}} \pm 0.53 \\
26.53^{\mathrm{b}} \pm 0.61 \\
28.10^{\mathrm{ab}} \pm 0.53 \\
27.73^{\mathrm{ab}} \pm 0.66\end{array}$ & $\begin{array}{l}0.68^{\mathrm{a}} \pm 0.01 \\
0.68^{\mathrm{a}} \pm 0.02 \\
0.67^{\mathrm{a}} \pm 0.03 \\
0.61^{\mathrm{ab}} \pm 0.02 \\
0.60^{\mathrm{ab}} \pm 0.04 \\
0.58^{\mathrm{b}} \pm 0.02\end{array}$ & $\begin{array}{l}10.21^{\mathrm{b}} \pm 0.35 \\
11.40^{\mathrm{ab}} \pm 0.36 \\
10.83^{\mathrm{ab}} \pm 0.33 \\
11.11^{\mathrm{ab}} \pm 0.66 \\
11.95^{\mathrm{a}} \pm 0.67 \\
11.54^{\mathrm{ab}} \pm 0.42\end{array}$ & $\begin{array}{l}659.53^{\mathrm{ab}} \pm 40.37 \\
637.58^{\mathrm{ab}} \pm 23.69 \\
692.98^{\mathrm{ab}} \pm 31.25 \\
595.88^{\mathrm{b}} \pm 18.57 \\
635.68^{\mathrm{ab}} \pm 49.14 \\
728.53^{\mathrm{a}} \pm 30.14\end{array}$ \\
\hline
\end{tabular}

$\mathrm{a}, \mathrm{b}$ Means with different letters in the same column are significantly different at $\mathrm{P} \leq 0.05$

G 1,2, 3, 4, 5 and 6 means Group1, 2, 3, 4, 5 and 6 . 


\section{REFFERENCES}

Anders, J. J., T. B. Romanczyk, I. K. Ilev, H. Moges, L. Longo, $X$. Wu, and R. W. Waynant, 2008. Light Supports Neurite Outgrowth of Human Neural Progenitor Cells in Vitro: The Role of P2Y Receptors. IEEE Journal of selected Topics in Quantum Electronics, 14(1): 118-125.

Attia Y.A., F. Bovera, W.S., EL-Tahawy EL-Hanoun A.M., AL-Harthi M.A., HABIBA H. I. 2015a. Productive and performance of rabbits does as affected by bee pollen and/or propolits, inulin and/or mannanoligosaccharide. World Rabbit Sci. 23: 273-282.

Attia, Y. A., R. S. Hamed, A. E. Abd Elhamid, H. A. Shahba and F. Bovera 2015b.Effect of inulin and mannanoligosaccharides compared with zincbacitracin on growing performance, nutrient digestibility and hematological profiles of growing rabbits. Anim. Prod. Sc., 55(1) 80-86.

Awaad, M. H. H. , A. M. Atta, Wafaa A. Abd El-Ghany, M. Imenawey, K. Ahmed; A. A. Hassan, A. A. Nada and G. A. Abdelaleem1 2011. Effect of a Specific Combination of MannanOligosaccharides and $\beta$-Glucans Extracted from Yeast Cell Wall on the Health Status and Growth Performance of Ochratoxicated Broiler Chickens Journal of American Science, 7(3).

Baselga, M., (2002). Line V. Rabbit genetic resources in Mediterranean.Countries International Center of Ciheam. pp. 231-242 (cited in Khalil and Baselga, 2002).

Bovera, F., S. Marono, C. Di Meo, G. Piccolo, F. Iannaccone and A. Nizza, 2010. Effect of mannanoligosaccharides supplementation on caecal microbial activity of rabbits .Animal (2010), 4:9, pp 1522-1527.
Cummings, J. H. and G.T. Macfarlane, 2002. Gastrointestinal effects of prebiotics. Br. J. Nutr.,87(Suppl.2): 145151 (Abstr.).

Duncan, D. B. (1955). Multiple ranges and multiple F test. Biometrics, 11: 1-42

El-Raffa A. M. (2000). Animal model evaluation of $\mathrm{V}$ Line Rabbits raised under Egyptian conditions. Egypt. Poultry Science 20:1003-1016.

El-Sheikh, A. M. H., E. A. Abdalla, Maysa and M. Hanafy 2009. Study on productive performance, hematological and immunological parameters in a local strain of chicken as affected by mannan oligosaccharides under hot climate condition. Egypt. Poult. Sci., (29) (I): 287-305.

Falcão-e-Cunha, L., L. Castro-Solla , L. Maertens, M. Marounek, V. Pinheiro, J. Freire and J. L. Mourão, 2007. Alternatives to antibiotic Growth performance in rabbit feeding: A Review. World Rabbit Sci. 2007, 15: $127-140$.

Garcia-Ruiz, A. I., A. Perez-Bonilla, P. Perez De Ayala, J. Eissen, G. Xicato, A. Trocino and S. D. Lukefahr 2008. Effect of Yeast $\beta$ Glucans on Rabbit Performances and Mortality from 35 to 63 Days of Age. 9th World Rabbit Congress - June 10-13-Verona - Italy.

Gardiner, T., 2000. $\beta$-glucan biological activities: A review, Glycoscience and Nutrition, 1, 1- 6.

Hawkey, C. M. and T. B. Dennett, 1989. A color atlas of comparative veterinary hematology Wolf Publishing Limited, London, England.

Hepler, O. E., 1966. Manual of Clinical Laboratory Methods. C.C.Thomas Publishing, Springfield.

Kocher A., P. Spring and D.M Hooge 2004. Summary analysis of postweaning rabbits trials with dietary mannan oligosaccharide. In: Animal production in Europe: the way forward 
in a changing world. Saint-Malo: Zoopole development. 261, 2.

NRC ,National Research Council, 1994.

Nutrient Requirements of Poultry. 9th

Ed. National Academy Press,

Washington, DC, USA.

SAS 2005. By SAS institute INC., Cary, NC, USA. SAS (r) proprietary software version 9.00.

Santin, E., A. Maiorka, M. Macari, M. Grecco, J. C. Sanchez, T. M. Okada and A. M. Myasaka 2001. Performance and intestinal mucosa development of broiler chickens fed diets containing Sacharomyces cerevisae cell wall. Journal of Applied Poultry Research .10:236-244.

Savage, T. F., P. F. Cotter, and E. I. Zakrzewska 1996. The effect of feeding a mannanoligosaccharide on immunoglobulins, plasma $\operatorname{IgA}$, and bile IgA of Wrolstad MW male turkeys. Poult Sci 75 (Suppl 1).

Shane, M. S., 2001. Mannan oligosaccharides in poultry nutrition: mechanism and benefits. In: Proc. Alltech's 17th Ann. Symp. Science
Technology in the Feed Industry. Ed. Lyons, T.P. \& Jacques, K.A., Nottingham University Press. pp. 65-77.

Shendare, R. C., M. A. Gongle2, A. B. Rajput1, B.V.Wanjari1 and S. M. Mandlekar, (2008). Effect of supplementation of MannoOligosaccharide and b-glucans on maize based meal on commercial broilers. Veterinary World, Vol.1(1):13-15.

Strickling, J. A., D. L. Harmon, K. A. Dawson and K. L. Gross, 2000. Evaluation of oligosaccharide addition to dog diets: influences on nutrient digestion and microbial populations. An Feed Sci \& Tech 86, 205-219.

Vetvicka, V., (2001). $\beta$-Glucans as imunomodulators. JANA 3: 31-34.

Wu, H. H., B. B. C. Weng, K. L. Chen, P.W. S. Chiou and B. Yu 2011. Effect of dietary supplementation of $\beta-1,3-1,6-$ glucan on reproductive performance and immunity of New Zealand White does and their pups. Livestock Sci., 135, 7075 . 


\section{تأثيرات إضافة المنان أوليجو سكريد والبيتا جلوكان في العليقة العلي علي الإنتاجية ومستوي المناعة

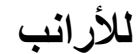

مروة عبدالله خربوش و أ.د.علاء محمد الرفهه و أ.د.أميرة إسماعيل الالبشاني و د. أحمد محمد عبد الهادي و * أ.د.

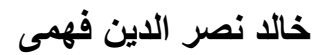

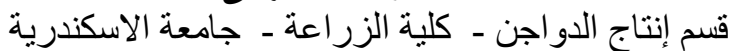

*قسم التغذية و التغذية الأكلينيكية ــ كلية الطب البراع البطرى- جامعة القاهرة

صمدت التجربة لدراسة تأثير اضافة توليفة من المنان أوليجو سكريد والبيتا جلوكان (الأجريموس) في العليقة

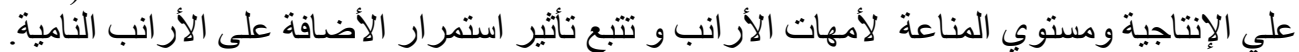
التجربة الأولى: كان العدد الكلى 64 أم

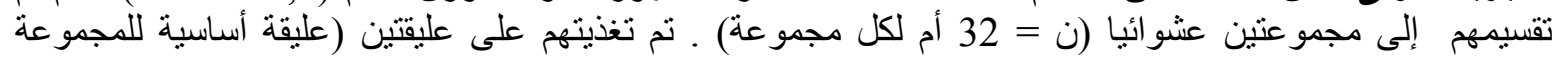

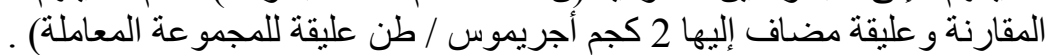

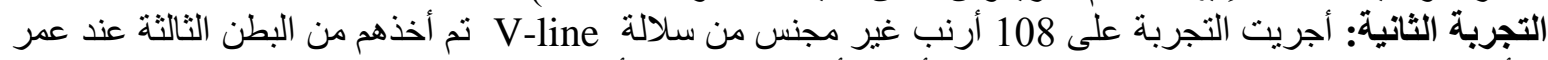

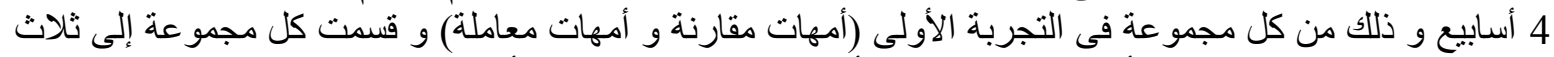

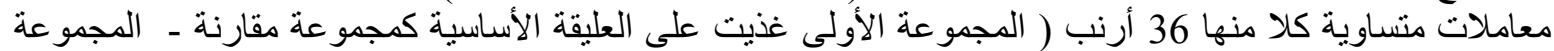
الثانية غذيت على العليقة الأساسية مضاف إليها اليها ا كجم أجريموس/طن - المجموعة الثالثة غذيت على الثلى العليقة الأساسية

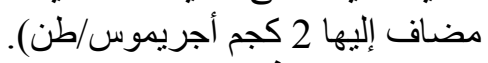

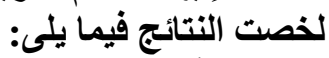

الأمهات التى غذيت التيت على عليقة مضاف إليها 2 كجم أجريموس / طن عليقة كمجمو عة معاملة سجلت حجم بطن

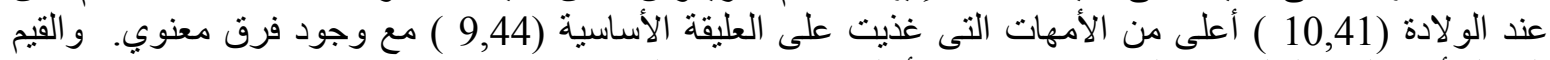

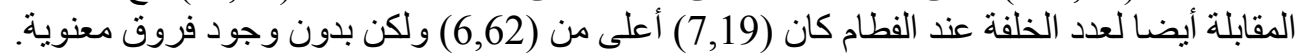

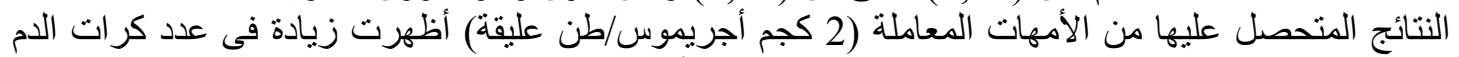

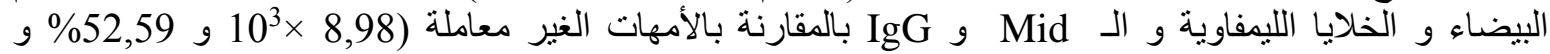

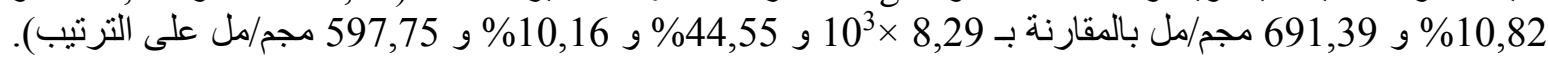

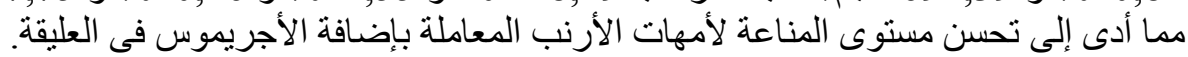

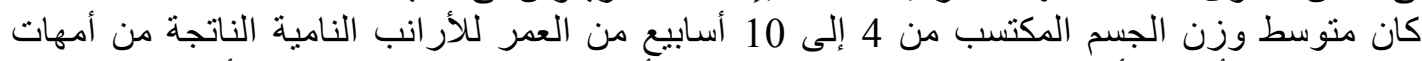

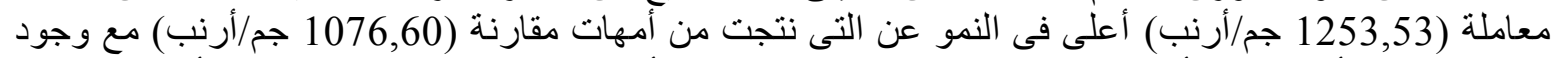

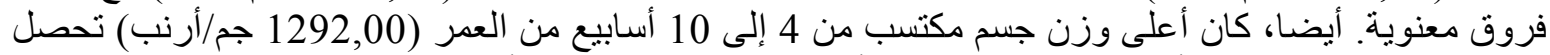

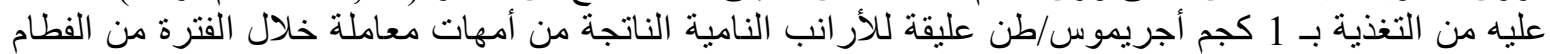
حتى عمر 10 أسابيع.

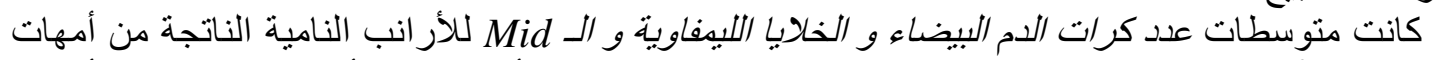

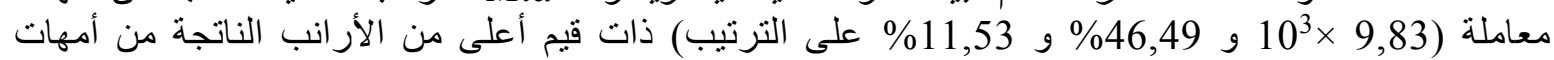

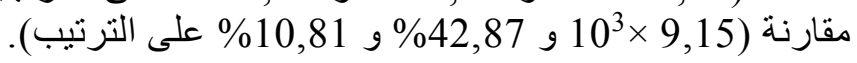

الخلاصة: اضافة المنان أوليجو سكريد والبيتا جلوكان (الأجريموس) في عليقة الأرانب حسنت بصورة معنوية حجم البطن عند الو لادة و الحالة المناعية للأمهات وكذللك وزن الجسم المكتسب التبن فى الفترة من 4 إلى 10 أسابيع و الحالة المناعية للأر انب النامية. 